\title{
Sleep complaints among Brazilian senior citizens from municipalities with different Human Development Indices ${ }^{1}$
}

\author{
Ariene Angelini dos Santos ${ }^{2}$ \\ Maria Filomena Ceolim ${ }^{3}$ \\ Anita Liberalesso $\mathrm{Neri}^{4}$
}

Purpose: To compare the occurrence of sleep complaints among senior citizens resident in the local communities of two municipalities with differing Human Development Indices (HDIs): Campinas, State of São Paulo (IDH = 0.852) and Parnaíba, State of Piauí (IDH = 0.674). Method: Descriptive study as part of the multicentric project going by the name of Frailty among Brazilian Senior Citizens (Fragilidade em Idosos Brasileiros - FIBRA). A total of 988 senior citizens were analysed, making use of a social and demographic questionnaire about sleep problems (Nottingham Health Profile); questions about naps (Minnesota Leisure Activity Questionnaire). The Chi-Square and Mann-Whitney tests were used in the analysis of the data, at a significance level of $5 \%(p<0.05)$. Results: The chronologically advantaged individuals in Parnaíba showed a higher incidence of sleep complaints when compared to the senior citizens of Campinas. There was a significant association between municipality and the following variables: number of sleep complaints, non-restoring sleep, precocious awakening, difficulty in falling and staying asleep. Conclusion: The nursing staff must intervene in favour of the promotion of health with actions that either reduce or prevent these sleep-related problems.

Descriptors: Aged; Geriatric Nursing; Social Vulnerability; Sleep.

\footnotetext{
${ }^{1}$ Paper extracted from Doctoral Dissertation "Cochilo e fragilidade: um estudo transversal sobre idosos do FIBRA Unicamp" presented to Universidade Estadual de Campinas, Brazil. Supported by CAPES.

2 Doctoral Student, Departamento de Enfermagem, Faculdade de Ciências Médicas, Universidade Estadual de Campinas, Brazil.

${ }^{3}$ PhD, Associate Professor, Departamento de Enfermagem, Faculdade de Ciências Médicas, Universidade Estadual de Campinas, Brazil.

${ }^{4} \mathrm{PhD}$, Full Professor, Faculdade de Educação, Universidade Estadual de Campinas, Brasil.
}

Corresponding Author:

Ariene Angelini dos Santos

Rua Luiz Turri, 47

Jardim Planalto

CEP: 37800-000, Guaxupé, MG, Brasil

E-mail: arieneangelini@yahoo.com.br 


\title{
Queixas de sono entre idosos brasileiros de municípios com diferentes índices de desenvolvimento humano
}

Objetivo: comparar a ocorrência de queixas de sono em idosos residentes na comunidade de dois municípios com diferentes índices de desenvolvimento humano (IDH): Campinas, $\mathrm{SP},(\mathrm{IDH}=0,852)$ e Parnaíba, $\mathrm{PI}$, (IDH=0,674). Método: estudo descritivo, parte integrante do projeto multicêntrico Fragilidade em Idosos Brasileiros (Fibra). Foram avaliados 988 idosos, utilizando-se questionário sociodemográfico, questões sobre queixas de sono (Perfil de Saúde de Nottingham); questões sobre cochilo (Minnesota Leisure Activity Questionnaire). Os testes qui-quadrado e Mann-Whitney foram utilizados na análise de dados, com nível de significância de 5\% $(p<0,05)$. Resultados: os idosos de Parnaíba apresentaram maiores porcentagens de queixas de sono se comparados aos idosos de Campinas. Houve associação significativa entre município e número de queixas de sono, sono não restaurador, despertar precoce, dificuldade para manter e para iniciar o sono. Conclusão: os enfermeiros devem intervir na promoção da saúde com ações que minimizem ou previnam esses problemas relativos ao sono.

Descritores: Idoso; Enfermagem Geriátrica; Vulnerabilidade Social; Sono.

\section{Quejas de sueño entre mayores brasileños de municipios con diferentes índices de desarrollo humano}

\begin{abstract}
Objetivo: comparar la ocurrencia de quejas de sueño en mayores residentes en la comunidad de dos municipios con diferentes Índices de Desarrollo Humano (IDH): Campinas ( $\mathrm{IDH}=0,852)$ y Parnaíba ( $\mathrm{IDH}=0,674)$. Método: estudio descriptivo parte integrante del proyecto multicéntrico Fragilidad en Mayores Brasileños (FIBRA). Fueron evaluados 988 de edad, utilizándose cuestionario sociodemográfico, cuestiones sobre quejas de sueño (Perfil de Salud de Nottingham); cuestiones sobre sueños (Minnesota Leisure Activity Questionnaire). Los testes Jue-cuadrado y Mann Whitney fueron utilizados en el análisis de datos, con nivel de significancia del $5 \%(p<0,05)$. Resultados: los mayores de Parnaíba presentaron mayores porcentajes de quejas de sueño se comparados a los mayores de Campinas. Hubo asociación significativa entre municipio y: número de quejas de sueño, sueño no restaurador, despertar precoz, dificultad en mantener y en iniciar el sueño. Conclusión: los enfermeros deben intervenir en la promoción de la salud con acciones que minimicen o precavan esos problemas relativos al sueño.
\end{abstract}

Descriptores: Anciano; Enfermería Geriátrica; Vulnerabilidad Social; Sueño.

\section{Introduction}

The growth in the Brazilian chronologically advantaged population is an important fact, because of its peculiar characteristics and also its consequences, considering that this phenomenon has occurred rapidly and within an underlying context of social inequality, a feeble economy, limited access to specialised support services and scarce financial resources, together with the lack of structural adaptations that would cater to this emerging age bracket ${ }^{1}$.
Ageing is, indeed, a heterogeneous phenomenon, which means that it occurs in different ways in different people. In addition, it can bring changes to the normal sleep pattern ${ }^{2}$, and this ranks among the most common complaints made by the senior citizens.

Sleep problems occur in more than half of senior citizens aged 65 or over ${ }^{3}$. Old age can bring changes regarding both the architecture and the quality of sleep ${ }^{4}$. There could be a reduction in the total time spent 
sleeping; increases in periods of being awake; greater number of naps and snoozes taken during the day; increased use of sleep-inducing medication; excessive sleepiness during the day; attention and memory problems; depression, falls and worsening of the quality of life ${ }^{4}$.

The harm that sleep disorders can bring to the general health of the chronologically advantaged has only just started to be explored. Recent works on the subject suggest that, with sleep deprivation, there could be a loss of cognition, the increase in sympathetic tonus and also intolerance to glucose. People who tend to have sleep of short duration are prone to an increased risk of developing cardiovascular disease and diabetes, as well an increase in mortality ${ }^{6}$. In this way, some authors are stressing the need to abandon the idea that these health patterns are normal and not harmful to the senior citizens? ${ }^{7}$.

Being a physiological process which is essential for the adequate function of the human organism, the quality and the impact of sleep on people's daily lives has become one of the main points that have warranted the attention of the researchers ${ }^{8}$.

It is believed that chronologically advantaged individuals within contexts of high social vulnerability are highly vulnerable to the effects of stress-causing factors, hence becoming more prone to health problems ${ }^{9}$ and also to changes to the normal sleep pattern. Thus, it is expected that the chronologically advantaged individuals living in a municipality with a lower Human Development Index (HDI) would assess their own sleep pattern in a more negative way than their counterparts in a municipality with a higher HDI.

A transversal study carried out in Brazil, with a total of 158 senior citizens with an average age of 70.2 years $(S D=8.2)$, of which $72 \%$ were women, had the ultimate aim of observing the relationship between changes to sleep patterns related to age, symptoms of insomnia and apnoea with social and economic variables and also regarding self-perceived health. The sleep pattern was appraised through the Mini-Sleep Questionnaire, at home interviews. The women and also the group with a lower educational level showed a greater frequency of symptoms of insomnia. The most chronologically advantaged of the individuals and also the group with best self-perception of health have shown a lower frequency of symptoms characteristic of sleep apnoea. A better perception of general health was normally associated with a better standard of sleep. The authors have reached the conclusion that the sleep pattern is influenced by social and economic characteristics such as age, gender, educational level and self-perception of health ${ }^{3}$.

The hypothesis that sleep problems are independently associated with a greater evidence of frailty among older men was tested in a prospective cohort study conducted in the United States. The universe of this study was 3133 gentlemen aged 67 or over. The complaints about poor quality of sleep, excessive sleepiness during the day, short duration of sleep, prolonged sleep latency, and fragmentation of sleep were more prevalent among the more frail of the senior citizens considered ( $p \leq 0.002$ for all parameters) when compared with the chronologically advantaged individuals who were not frail. After an adjustment to allow for minor factors of confusion, the self-report of poor quality of sleep $(O R=1.28$, IC $1.09-1.50)$, sleep efficiency below 70\% (OR $=1.37$, IC 1.12-1.67) and sleep latency of more than 60 minutes $(O R=1.42$, IC 1.10-1.82) were independently associated to a greater likelihood of frailty. The authors reached the conclusion that sleep complaints, including self-reported poor quality of sleep, sleep efficiency and prolonged sleep latency, are independently associated to a greater evidence of frailty ${ }^{10}$.

The prevalence of sleep complaints has also shown itself to be high in a research conducted in Iran with 1409 men and 1685 women, with an average age of 43.57 years ( $S D=17.5)$, in order to establish the occurrence of sleep problems and also the subjective quality of sleep. Women, chronologically advantaged individuals, widowed people and separated couples presented the most important risks of sleep problems ${ }^{11}$.

In the light of the above, it seems important, and also highly relevant, to carry out studies about the sleeping habits of senior citizens, as the sleep problems which afflict them cause great dissatisfaction, as well as affecting the physical and cognitive health and the quality of life of this emerging section of the population. Thus, studies have shown that there is a high rate of sleep problems among the elderly, especially when these problems are associated to comorbidities, having a negative effect on the general health of this age group.

Thus, the health professionals may take specific courses of action with regard to the poor quality of sleep among this population, thereby preventing, minimising or solving these problems. From this perspective, for the nursing assistance to be provided with quality, the nurse needs to be well aware of the reality that surrounds the case, in a conscientious, competent, technical and 
scientific way, with it also being necessary to have a thought about these sleep problems shown by the client.

Research that has compared the frequency of complaints about sleep problems among senior citizens in municipalities with different HDIs is very scarce within our context, and there is a dearth of these studies in Brazilian literature. Thus, the main purpose and aim of this work has been that of comparing the occurrence of complaints about sleep problems among senior citizens resident in the local communities in two municipalities with different HDIs.

\section{Method}

This is a descriptive and transversal study, based on the assumptions of the quantitative method of investigation. This is an extract from the project known as Frailty in Brazilian Senior Citizens (Fragilidade em Idosos Brasileiros - FIBRA), developed in 17 Brazilian cities, being carried out by researchers in four different Universities in the country. This is a multicentric and multidisciplinary project which investigates the characteristics and also the prevalence of the biological frailty syndrome and other associated variables, in probabilistic samples of senior citizens aged 65 and over.

\section{Subjects}

The subjects of this study were 988 chronologically advantaged individuals in the communities of two municipalities with differing Municipal Human Development Indices (HDI-M), namely Campinas, State of São Paulo (IDH $=0.852, \mathrm{n}=689$ ) and Parnaíba, State of Piauí ( $\mathrm{IDH}=0.674, \mathrm{n}=299$ ), selected due to the disparity that has been observed between the HDIs of these two Brazilian cities. These senior citizens were obtained in urban census sectors, and were chosen at random. The number of urban census sectors to be selected corresponded to the ratio between the number of chronologically advantaged individuals intended for the sample in each location and the number of urban census sectors in each city. The sampling plan also established that the minimum size of the sample as estimated for Campinas, a large city with more than 1 million people, was 601 subjects with a sample error of $4 \%$. In the case of Parnaíba, with less than 1 million people, the estimate was 385 senior citizens, for a sampling error of $5 \%$. In each city, there was pre-establishment of quotas of urban census sectors to be visited by the recruiters (90 in Campinas and 60 in Parnaíba). In each census sector, there was the extraction of a sample with a size corresponding to their presence in the real distribution of the chronologically advantaged population in the chosen sectors, according to data from the Brazilian Institute for Geography and Statistics (IBGE). All the samples should include quotas of men and women, belonging to the following age brackets: 65 to 69,70 to 74,75 to 79 and 80 years and over, while respecting the proportionality in the distribution of these segments in the chronologically advantaged population resident in the urban zone. For each census sector, plans were made for the recruitment of an excess sample $25 \%$ bigger than the intended number of senior citizens, respecting the criteria regarding gender and age, to compensate for possible losses at the moment of data collection.

\section{Criteria for inclusion and exclusion}

The participants in this study have met the following criteria for inclusion: be 65 years old or over, understand the instructions, and also be a permanent resident in the city of domicile and the respective censor sector. The criteria for exclusion that have been adopted, through observation, are the following:

- senior citizens with serious cognitive disorder, shown through problems such as loss or memory, attention or spatial or temporal orientation, and respective communication to or observation by the recruiters;

- senior citizens who are confined to a wheelchair or who are provisionally or permanently bedridden;

- those afflicted with serious consequences of a stroke, with localised loss of strength and/or aphasia;

- people with advanced or unstable Parkinson's Disease with serious loss of motricity, speech or affectivity;

- those patients with serious loss of sight or hearing, which could be a serious obstacle to communication; - the chronologically advanced people who are terminally ill.

\section{Procedures and instruments for data collection}

After the reading and respective signing of the Free and Clarified Consent Declaration, there was the start of data collection made by undergraduates, graduate students and also professional people from the health area who have been duly trained, this process taking from September 2008 to June 2009. The data was collected in one single session, in schools, churches, basic health units (Unidades Básicas de Saúde - UBSs), convenience centres and clubs. The place was agreed with the senior citizens at the moment of recruitment for the survey. The chronologically advantaged individuals were then appraised using the Mini Exam for Mental State (Mini Exame 
do Estado Mental - MEEM), a test for tracking cognitive changes. The participants who got scores above the cut-off mark for the instrument as mentioned, according to their educational level, took part in this study.

Social and demographic data (gender, age, colour or ethnic origin, marital status, educational level, family income, family structure and retirement status) were collected by means of a special instrument developed by the researchers of the FIBRA study.

For the assessment of complaints regarding sleep problems, there was the use of five scalar items of the instrument known as the Nottingham Health Profile (Perfil de Saúde de Nottingham - PSN), as validated for Brazil ${ }^{12}: 1$. Have you taken medication in order to sleep? (Use of sleeping pills); 2. Have you ever got up very early and then not gone back to sleep? (Precocious awakening); 3. Have you remained awake most of the night? (Difficulty to sleep); 4. Have you taken a long time to fall asleep? (Difficulty to start sleeping); 5. Did you sleep badly at night? (Non-restoring sleep). The answers were of the dichotomic variety (Yes or No), referring to the last twelve months. If the senior citizen gave an affirmative answer to any one of the five PSN questions, then he or she shall be considered as a person with complaints of sleep problems, according to the criteria established in the Diagnostic and Statistical Manual of Mental Disorders, Fourth Edition (DSM IV) ${ }^{13}$.

The assessment of naps taken during the day was made based on self-reporting, using a question of the Minnesota Leisure Time Activities Questionnaire ${ }^{14}$, incorporated to the instrument used in the FIBRA study. The senior citizen was asked if he or she ever slept or took a nap during the day (yes or no) and, in affirmative cases, how many hours a day. Any report of a daily nap or snooze of more than 90 minutes was considered as a sleep disorder.

\section{Ethical procedures}

All the ethical principles which govern research with humans were observed and fully respected, according to Resolution No. 196/96 of the National Health Council (Conselho Nacional de Saúde). The use of the data from the FIBRA study was authorised by the co-ordinator of the study. This study has also been approved by the Research Ethics Committee, with an addendum to the FIBRA study (Opinion Statement No. 208/2007), in 27 September 2011.

\section{Data analysis}

The data was analysed with the help of the programme known as SPSS (Statistical Package for the Social Sciences), version 17.0. Descriptive, percentage and simple frequency count analysis of the variables was performed. The chi-square test was then used to appraise the association between the nominal variables. For the case of inferential statistics, the Mann-Whitney test was used to compare the two independent groups, considering that the distribution of the data is not normal (non-Gaussian) according to the Kolmogorov-Smirnov test. The level of significance used for the statistical tests was $5 \%$, which means $p<0.05$.

\section{Results}

Table 1 shows the main social, economic and demographic characteristics of the chronologically advantaged subjects in Campinas $(n=689)$ and Parnaíba ( $n=299$ ) as included in the present study.

Table 1 - A comparative analysis of the social, economic and demographic characteristics of the universe of chronologically advantaged people who participated in the FIBRA study. Campinas, State of São Paulo, and Parnaíba, State of Piauí, Brazil, 2008/2009

\begin{tabular}{|c|c|c|c|c|c|}
\hline \multirow{2}{*}{ Characteristics } & \multicolumn{2}{|c|}{ Campinas/SP } & \multicolumn{2}{|c|}{ Parnaíba/PI } & \multirow{2}{*}{$p$-value } \\
\hline & $\mathbf{n}$ & $\%$ & $\mathbf{n}$ & $\%$ & \\
\hline \multicolumn{6}{|l|}{ Gender } \\
\hline Female & 474 & 68.8 & 172 & 57.5 & 0.001 \\
\hline Male & 215 & 31.2 & 127 & 42.5 & \\
\hline \multicolumn{6}{|l|}{ Marital status } \\
\hline Single & 37 & 5.4 & 26 & 8.7 & 0.111 \\
\hline Married & 378 & 55.1 & 161 & 54.0 & \\
\hline Separated & 51 & 7.4 & 14 & 4.7 & \\
\hline Widowed & 220 & 32.1 & 97 & 32.6 & \\
\hline
\end{tabular}


Table 1 - (continuation)

\begin{tabular}{|c|c|c|c|c|c|}
\hline \multirow{2}{*}{ Characteristics } & \multicolumn{2}{|c|}{ Campinas/SP } & \multicolumn{2}{|c|}{ Parnaíba/PI } & \multirow{2}{*}{ p-value } \\
\hline & $n$ & $\%$ & $n$ & $\%$ & \\
\hline \multicolumn{6}{|l|}{ Age } \\
\hline 65 to 69 & 253 & 36.8 & 114 & 38.1 & 0.140 \\
\hline 70 to 74 & 228 & 33.1 & 82 & 27.4 & \\
\hline 75 to 79 & 136 & 19.7 & 59 & 19.8 & \\
\hline 80 or over & 72 & 10.4 & 44 & 14.7 & \\
\hline \multicolumn{6}{|l|}{ Education } \\
\hline Never been to school & 114 & 16.5 & 107 & 35.9 & $<0.001$ \\
\hline Adult Literacy Classes & 17 & 2.5 & 8 & 2.7 & \\
\hline Primary School & 367 & 53.3 & 105 & 35.2 & \\
\hline Middle School & 88 & 12.8 & 39 & 13.1 & \\
\hline $\begin{array}{l}\text { High School (Científico, Teacher } \\
\text { Training or Clássico) }\end{array}$ & 47 & 6.8 & 28 & 9.4 & \\
\hline University & 54 & 7.8 & 11 & 3.7 & \\
\hline Master's Course or Doctorate & 2 & 0.3 & 0 & 0.0 & \\
\hline \multicolumn{6}{|l|}{ Colour or Ethnic Origin } \\
\hline White & 507 & 73.9 & 103 & 34.8 & $<0.001$ \\
\hline Black & 64 & 9.3 & 20 & 6.8 & \\
\hline Coloured (Mulatto, Cabocla and Sepia) & 99 & 14.4 & 168 & 56.7 & \\
\hline Native Brazilian & 6 & 0.9 & 2 & 0.7 & \\
\hline Asian-Brazilian & 10 & 1.5 & 3 & 1.0 & \\
\hline \multicolumn{6}{|l|}{ Retired } \\
\hline Yes & 481 & 70.0 & 274 & 92.2 & $<0.001$ \\
\hline No & 206 & 30.0 & 23 & 7.8 & \\
\hline \multicolumn{6}{|l|}{ Living Arrangements } \\
\hline Alone & 107 & 15.6 & 19 & 6.4 & $<0.001$ \\
\hline With spouse & 187 & 27.3 & 29 & 9.7 & \\
\hline Descendants & 155 & 22.7 & 76 & 25.5 & \\
\hline Spouse and descendants & 166 & 24.3 & 117 & 39.3 & \\
\hline Other external relatives & 36 & 5.3 & 19 & 6.4 & \\
\hline Other mixed arrangements & 33 & 4.8 & 38 & 12.7 & \\
\hline \multicolumn{6}{|l|}{ Family Income } \\
\hline Less than 1 minimum wage (SM) & 39 & 6.5 & 38 & 14.4 & $<0.001$ \\
\hline $1.1-3.0 \mathrm{SM}$ & 234 & 38.8 & 157 & 59.7 & \\
\hline $3.1-5.0 \mathrm{SM}$ & 167 & 27.7 & 37 & 14.1 & \\
\hline $5.1-10.0 \mathrm{SM}$ & 116 & 19.2 & 16 & 6.1 & \\
\hline $10.0 \mathrm{SM}$ or more & 47 & 7.8 & 15 & 5.7 & \\
\hline
\end{tabular}

${ }^{*} \mathrm{p}$-value according to the chi-square test: significant results in bold.

In Table 1, we can see that according to the ChiSquare test there has been a significant correlation between the municipality and the following other variables: gender, educational level, colour or ethnic background, retiree status, housing arrangement and family income brackets.

Table 2 shows the main characteristics of the sleep patterns of the participating senior citizens.
According to the comparative analysis shown in Table 2, using the Chi-Square method, there has been significant correlation between the municipality and the following variables: sleep problems, non-restoring sleep, precocious awakening, difficulty in falling asleep, difficulty in staying asleep.

Table 3 shows the results of the comparative analysis for variables such as age, family income and number of sleep problems. 
Table 2 - A comparative analysis of the sleep characteristics of the senior citizens participating in the FIBRA study, for the cities of Campinas (State of São Paulo) and Parnaíba (State of Piauí), Brazil, 2008/2009

\begin{tabular}{|c|c|c|c|c|c|}
\hline \multirow{2}{*}{ Characteristics } & \multicolumn{2}{|c|}{ Campinas / SP } & \multicolumn{2}{|c|}{ Parnaíba / PI } & \multirow{2}{*}{ p-value } \\
\hline & $\mathrm{n}$ & $\%$ & $\mathbf{n}$ & $\%$ & \\
\hline \multicolumn{6}{|l|}{ Sleep problems } \\
\hline Yes & 406 & 59.7 & 223 & 75.9 & $<0.001$ \\
\hline No & 274 & 40.3 & 71 & 24.1 & \\
\hline \multicolumn{6}{|l|}{ Daytime naps } \\
\hline Absent or less than 90 minutes & 621 & 90.1 & 262 & 87.6 & 0.240 \\
\hline 90 minutes or more & 68 & 9.9 & 37 & 12.4 & \\
\hline \multicolumn{6}{|l|}{ Non-restoring sleep } \\
\hline Yes & 191 & 28.2 & 102 & 35.2 & 0.031 \\
\hline No & 486 & 71.8 & 188 & 64.8 & \\
\hline \multicolumn{6}{|l|}{ Use of medication to induce sleep } \\
\hline Yes & 133 & 19.7 & 60 & 20.5 & 0.782 \\
\hline No & 542 & 80.3 & 233 & 79.5 & \\
\hline \multicolumn{6}{|l|}{ Precocious awakening } \\
\hline Yes & 234 & 34.5 & 143 & 48.8 & $<0.001$ \\
\hline No & 444 & 65.5 & 150 & 51.2 & \\
\hline \multicolumn{6}{|l|}{ Difficulty in staying asleep } \\
\hline Yes & 141 & 20.8 & 106 & 36.2 & $<0.001$ \\
\hline No & 537 & 79.2 & 187 & 63.8 & \\
\hline \multicolumn{6}{|l|}{ Difficulty in falling asleep } \\
\hline Yes & 192 & 28.3 & 114 & 39.0 & 0.001 \\
\hline No & 486 & 71.7 & 178 & 61.0 & \\
\hline
\end{tabular}

*p-value according to the Chi-Square test: significant results in bold.

Table 3 - A comparative analysis of age, family income and number of sleep problems reported by the senior citizens participating in the FIBRA study. Campinas, State of São Paulo, and Parnaíba, State of Piauí - Brazil, 2008/2009

\begin{tabular}{|c|c|c|c|c|c|c|c|}
\hline & Mean & Median & $\mathrm{SD}^{*}$ & Minimum & Maximum & z & $p$-value ${ }^{\dagger}$ \\
\hline \multicolumn{8}{|l|}{ Age } \\
\hline Campinas & 71.95 & 71.00 & 5.2 & 65 & 90 & \multirow{2}{*}{-1.162} & \multirow{2}{*}{0.245} \\
\hline Parnaíba & 72.80 & 72.00 & 5.5 & 65 & 88 & & \\
\hline \multicolumn{8}{|l|}{$\mathrm{Fl}^{\ddagger}$} \\
\hline Campinas & $2,043.07$ & $1,500.00$ & $2,307.4$ & 0 & $24,000.00$ & \multirow{2}{*}{ - 7.377} & \multirow{2}{*}{$<0.001$} \\
\hline Parnaíba & $1,378.97$ & 930.00 & $1,911.4$ & 100,00 & $25,000.00$ & & \\
\hline \multicolumn{8}{|l|}{ NSP§ } \\
\hline Campinas & 1.4 & 1.0 & 1.53 & 0 & 6.0 & \multirow{2}{*}{-4.783} & \multirow{2}{*}{$<0.001$} \\
\hline Parnaíba & 1.9 & 2.0 & 1.62 & 0 & 5.0 & & \\
\hline
\end{tabular}

*SD $=$ Standard Deviation

tp-value according to the Mann-Whitney test: significant results in bold

${ }^{\ddagger} \mathrm{FI}=$ Family Income

${ }^{\mathrm{s} N S P}=$ Number of sleep problems

According to the Mann-Whitney test, there has been a significant difference between the two municipalities here considered, in terms of family income and also regarding the number of sleep-related problems, as shown in Table 3.

\section{Discussion}

The data of the present study reinforce the importance of an assessment of the sleep patterns present in Brazilian senior citizens, especially for those based in areas where the Human Development Index (HDI) is low, who often live under precarious conditions with limited access to the Brazilian public health service (Sistema Único de Saúde - SUS).

This is the first Brazilian study with this focus, which has also not been sufficiently exploited in the international scenario. The social inequality which has been found among senior citizens has been shown to 
favour the importance of this analysis for sleep problems.

There has been a predominance of women within the group of participants in this study, a factor which some authors have caused the "feminisation of advanced age". The fact that women have a greater possibility of survival can be explained by their lower exposure to occupational risks, lower mortality from external causes, and also different attitudes in relation to illness, as they use health services often when compared to men, who suffer higher mortality rates ${ }^{15}$.

In relation to educational level, the senior citizens of the municipality with the lower HDI (Parnaíba, State of Piauí) are mostly illiterate and have a lower educational level than the chronologically advantaged subjects of Campinas, State of São Paulo (where the HDI is higher). These results reflect one of the main aspects of social inequality in Brazil and matches the results obtained in other research studies carried out in gerontology1.

Most senior citizens earn between 1.1 and 3.0 minimum wages, but the average income of the chronologically advantaged in Campinas is higher than that of senior citizens in Parnaíba. In most cases, this income comes from retirement pensions. Researchers suggest that retirement pensions have become the only source of income for 12 million Brazilian families ${ }^{16}$. In poor families, in many cases the senior citizen supports the family or takes care of the grandchildren while his or her children work outside the home ${ }^{17}$.

In the present study, we see a high percentage of senior citizens in Parnaíba living with their children under the same roof. In China, about $70 \%$ of chronologically advantaged people live with their children. In our country, we have seen an increase in the number of senior citizens living with their children, meaning that many generations coexist under one roof. This coresidence may be caused by lack of economic and/or physical independence of the senior citizen, but at the same time this can be beneficial both for the senior citizen as also for his or her children, meaning an improvement in living conditions ${ }^{1}$.

In relation to sleep problems, most senior citizens said that they have this kind of disorder. The most common problem mentioned was non-restoring sleep, followed by precocious awakening, difficulty in getting to sleep, use of medication to sleep, and daytime naps. These findings were confirmed by other studies which were found in the specialised literature about sleep patterns in senior citizens ${ }^{2,5,18}$.

The senior citizens in Parnaíba mentioned more sleep problems when compared to the chronologically advantaged people from Campinas. Sleep problems are very common among senior citizens, women, and widowed people ${ }^{11}$, especially among those of low social or economic class ${ }^{19}$, a fact which could explain the greater presence of sleep problems among senior citizens living in the municipality with the lower HDI. Financial difficulties could generate concerns that could, in turn, interfere with sleep patterns ${ }^{20}$. In addition, living under precarious conditions means that there is limited access to public services such as education and health, thus interfering in the behaviour patterns to prevent the disease and also in its early detection, such as sleep problems. ${ }^{21}$

In the present study, some senior citizens have mentioned that they take daytime naps of 90 minutes or more. The poor quality of night sleep can, indeed, generate an excess of daily sleepiness and hence lead to daytime naps, whether intentional or not. Research shows that the main factors related to daytime naps among senior citizens are: night sleep disorders, changes to the sleep-wake cycle related to age, comorbidities and mental challenges ${ }^{20}$. Even though there are still but a few studies about the characteristics of naps among the chronologically advantaged population, research suggests that naps can actually be beneficial to individuals, depending on the time of day and also the duration of the nap. Short naps may be more beneficial than taking naps for long periods ${ }^{22}$. Studies also show that the habit of taking long snoozes during the day has been associated to health problems and psychological problems ${ }^{23}$, and also to a serious risk factor for cognitive handicap ${ }^{24}$.

In the present study, there was no significant difference between senior citizens in Campinas and in Parnaíba in relation to the habit of taking daytime naps for long periods during the day. Some authors say that the prevalence of daytime naps depends on the place and also the population under study, as also the way in which this nap has been defined in the research protocol ${ }^{22}$.

\section{Conclusion}

The senior citizens of Parnaíba have shown larger percentages of sleep problems when compared to the chronologically advantaged people of Campinas. There has also been a significant association between the municipality and specific complaints about non-restoring sleep, precocious awakening, difficulty in falling asleep, and difficulty in staying asleep, all these being more common in Parnaíba. 
This knowledge is important for the development of strategies that can cater to the growing needs of this emerging age bracket, given that inadequate sleep could affect physical and cognitive health, as well as generating dissatisfaction and having a negative impact on the quality of life of the chronologically advantaged. Thus, nursing staff shall intervene for the promotion of health, through actions that either reduce or prevent these sleep-related problems.

In this perspective, future studies may be developed in order to check the presence of a relationship between sleep problems and problems involving physical health, as also cognitive decline, due to their relevance and also to the fact that they have not been addressed in the present study.

\section{References}

1. Santos AA, Pavarini SCI, Brito TRP. Perfil dos idosos com alterações cognitivas em diferentes contextos de vulnerabilidade social. Esc Anna Nery. 2010;14(3):496503.

2. Costa SV, Ceolim MF, Neri AL. Problemas de sono e suporte social: estudo multicêntrico Fragilidade em Idosos Brasileiros. Rev. Latino-Am. Enfermagem. 2011;19(4):920-7.

3. Oliveira BHD, Yassuda MS, Cupertino APFB, Neri $A L$. Relações entre padrão do sono, saúde percebida e variáveis socioeconômicas em uma amostra de idosos residentes na comunidade: Estudo PENSA. Ciênc. saúde coletiva. 2010; 15(3):851-60.

4. Kryger M, Monjan A, Bliwise D, Ancoli-Israel S. Sleep, health and aging: bridging the gap between science and clinical practice. Geriatrics. 2004;59(1):24-30.

5. Ancoli-Israel S. Sleep and its disorders in aging populations. Sleep Medicine. 2009;10:S7-S11.

6. Al Lawati NM, Patel SR, Ayas NT. Epidemiology, risk factors, and consequences of obstructive sleep apnea and short sleep duration. Prog Cardiovasc Dis. 2009;51(4):285-93.

7. Cunha MCB, Zanetti ML, Hass JV. Sleep Quality in Type 2 Diabetics. Rev. Latino-Am. Enfermagem. 2008;16(5):850-5.

8. Furlani R, Ceolim MF. Sleep quality of women with gynecological and breast cancer. Rev. Latino-am. Enfermagem. 2006;14(6):872-8.

9. Santos AA, Pavarini SCI. Perfil dos cuidadores de idosos com alterações cognitivas em diferentes contextos de vulnerabilidade social. Rev Gaúcha Enferm. 2010;31(1):115-22.
10. Ensrud KE, Blackwell TL, Redline $S$, Ancoli-Israel $S$, Paudel ML, Cawthon PM, Dam TT, Barrett-Connor E, Leung PC, Stone KL. Sleep disturbances and frailty status in older community-dwelling men. J Am Geriatr Soc. 2009;57(11):2085-93.

11. Asghari A, Farhadi M, Kamrava SK, Ghalehbaghi B, Nojomi M. Subjective Sleep Quality in Urban Population. Arch Iran Med. 2012; 15(2):95-8.

12. Teixeira-Salmela LF, Magalhães LC, Souza AC, Lima MC, Magalhães RC, Goulart F. Adaptação do Perfil de Saúde de Nottingham: um instrumento simples de avaliação de qualidade de vida. Cad Saúde Pública. 2004;20(4):905-14.

13. American Psychiatric Association [internet]. Diagnostic and Statistical Manual of Mental Disorders, Fourth Edition [acesso 12 fev 2010]. Disponível em: http:www.psych.org

14. Taylor HL, Jacobs DR, Schucker B, Knudsen J, Leon AS, Debacker G. A questionnaire for the assessment of leisure time physical activities. J Chron Dis. 1978;31:741-55.

15. Souza LM, Morais EP, Barth QCM. Socioeconomic and demographic characteristics and health condition of elderly people from a family health program in Porto Alegre, Brazil. Rev. Latino-am. Enfermagem. 2006;14(6): 901-6.

16. Areosa SVC, Areosa AL. Envelhecimento e dependência: desafios a serem enfrentados. Texto \& Contexto Enferm. 2008;7(1):138-50.

17. Souza RFS, Skubs T, Brêtas ACP. Envelhecimento e família: uma nova perspectiva para o cuidado de enfermagem. Rev Bras Enferm. 2007;60(3):263-67.

18. Ancoli-Israel S, Ayalon L, Salzman C. Sleep in the elderly: normal variations and common sleep disorders. Harv Rev Psychiatry. 2008;16(5):279-86.

19. Gu D, Sautter J, Pipkin R, Zeng Y. Sociodemographic and health correlates of sleep quality and duration among very old Chinese. Sleep. 2010;33(5):601-10.

20. Barichello E, Sawada NO, Sonobe HM, Zago MMF. Quality of Sleep in Postoperative Surgical Oncologic Patients. Rev. Latino-Am. Enfermagem. 2009;17(4):481-8.

21. Guimarães RM, Romanelli G. A inserção de adolescentes no mercado de trabalho através de uma ONG. Psicol Estudo. 2002;7(2):117-26.

22. Martin JL, Ancoli-Israel S. Napping in older adults. Sleep Med Clin. 2006;177-86.

23. Baker FC, Wolfson AR, Lee KA. Association of sociodemographic, lifestyle and health factors with sleep quality and daytime sleepiness in women: findings from 
the 2007 National Sleep Foundation "Sleep in America Pool". J Womens's Health. 2009;18(6):841-9.

24. Ohayon MM, Vecchierini MR. Daytime sleepiness and cognitive impairment in the elderly population. Arch Intern Med. 2002;162:201-8. 